\title{
Развитие НКО как поставщиков социальных услуг в регионах Дальневосточного округа
}

Развитие некоммерческого сектора в сфере социального обслуживания населения относится к одному из приоритетных направлений современной государственной социальной политики в Российской Федерации. Социальное государство в России все больше приобретает характер социально сервисного. Происходящие изменения соответствуют основным трендам, характерным социальным государствам зарубежных стран, имеющих уже достаточно длительный период преобразований, начавшихся в конце 1980-х - начале 1990-х годов, основу которых составляет развитие социального партнёрства государства с организациями некоммерческого и коммерческого секторов в решении социальных проблем. Актуальность исследования происходящих процессов в отечественной практике социального обслуживания населения определяется изменением роли государства в сфере социальных услуг и становлением организаций некоммерческого сектора как производителей социальных услуг в субъектах РФ, различающихся условиями развития НКО.

В России в 1990-е годы происходил переход к новым социально-экономическим условиям, связанным со становлением частной собственности. В этот период формировалась и соответствующая система социальной защиты как система государственных гарантий прав российских граждан на социальное обеспечение и социальное обслуживание. Происходящие процессы целенаправленного разгосударствления экономической сферы длительный период практически не затрагивали социальную сферу. Государство, оставаясь доминирующим институтом социальной сферы, в частности социальной защиты, выступало одновременно организатором социального обеспечения и социального обслуживания, фрормируя новые учреждения, способные обеспечивать многообразные социальные потребности граждан в условиях возрастания объективных социальных рисков, реформатором прежних компонентов системы и исполнителем основных функций по реализации актуальных социальных обязательств перед населением. Со временем объективная общественная потребность в повышении качества социальных услуг неизбежно актуализировала вопрос о диверсификации сложившейся в конце 1990-х - начале 2000-х годов системы и изменении роли государства. Диверсифицированная система социальных услуг, представляя один из способов снижения нагрузки с государства, включает наряду с государственными учреждениями социального обслуживания общественные, некоммерческие, частные организации, индивидуальных предпринимателей, добровольцев и других исполнителей социальных услуг. Второе десятилетие XXI столетия характеризуется существенными институциональными изменениями в сфере социального обслуживания российского общества, появлением новых норм, регулирующих развитие этой сферы, новых участников производства социальных благ, механизмов их включения в число исполнителей услуг, перераспределением полномочий и фрункций между основными участниками социального обслуживания. В со-

(C) Старшинова А. В., Платонова Л. А., 2020

СТАРШИНОВА Алевтина Викторовна, д-р социол. наук, профессор кафедры социальной работы Уральского федерального университета (с. Екатеринбург). E-mail: a.v.starshinova@urfu.ru

ПЛАТОНОВА Лилия Алексеевна, магистрант кафедры социальной работы Уральского федерального университета (е. Екатеринбург). E-mail: lilyapla@yandex.ru 
временных условиях государство, гарантируя обеспечение социальных прав граждан, начинает выполнять преимущественно фрункцию заказчика услуг, при этом создаются государственные стандарты предоставления услуг и контролируется качество их исполнения. В регионах государственные органы управления, заинтересованные в развитии негосударственного сектора в сорере социального обслуживания населения, проводят активную работу по вовлечению в производство социальных услуг некоммерческих организаций [2, 72-91; 26].

Социально-ориентированные $\mathrm{HKO}$ (СОНКО), представляя собой новый институт гражданского общества в России, создаются и функционируют в интересах определенных социальных групп для решения их социальных проблем. Их правовое, организационное оформление начинается с принятия закона РФ № 40 "О внесении изменений в отдельные законодательные акты Российской Федерации по вопросу поддержки социально ориентированных некоммерческих организаций" от 05.04.2010 в 2010 году, в котором были определены основные меры их поддержки и преимущества. По фредеральной Программе поддержки СОНКО, принятой в 2011 году, фиинансовая помощь им осуществляется в виде грантов, субсидий из бюджетов разного уровня на условиях конкурсного отбора $[1$, с. 66-73]. В создании конкретных условий вхождения СОНКО в сферу социальных услуг решающим был Федеральный закон № 442 "Об основах социального обслуживания граждан в Российской Федерации" от 28.12.2013, вступивший в действие в 2015 году. В законе установлены конкретные механизмы участия СОНКО на рынке услуг - реестры СОНКО, поставщиков социальных услуг, ответственных исполнителей общественно полезных услуг, разработаны критерии включения в них. В регионах формируется порядок финансирования на выполнение мероприятий в виде субсидии и компенсации за предоставленные НКО населению услуги, развивается система грантов на реализацию социальных проектов НКО, утверждаются требования к отчетности при компенсации расходов за предоставленные населению услуги. В настоящее время разработаны и утверждены стандарты оказания и качества услуг, индивидуальные программы получателей социальных услуг (ИППСУ). Показатели, свидетельствующие об увеличении в регионах численности СОНКО, принимаются во внимание при оценке эфрективности региональных управленческих структур и должностных лиц.

В статье представлены результаты исследования, в котором акцент сделан на изучение изменений в сорере социальных услуг на региональном уровне. Анализ проведен на материалах двух регионов Дальневосточного dpeдерального округа - Республике Саха (Якутия) и Хабаровского края. В 2018 году среди 85 субъектов РФ в рейтинге по итогам реализации механизмов поддержки социально ориентированных некоммерческих организаций и социального предпринимательства, обеспечения доступа негосударственных организаций к предоставлению услуг в социальной сфрере Хабаровский край занял одно из лидирующих мест - 3 место, набрав 36, 58 баллов, а Республика Саха (Якутия) - 7 место с суммой баллов 32,10 [10]. По сути, эти регионы оказались в числе лидеров в развитии некоммерческого сектора социальных услуг. Приведенные показатели демонстрируют наличие в Дальневосточном федеральном округе продвинутых территорий с точки зрения развития негосударственного сектора в социальной сфрере, прежде всего, социально ориентированных НКО. Цель данной статьи состоит в том, чтобы проанализировать основные фракторы, обеспечившие продвижение российских регионов на Дальнем Востоке РФ в развитии некоммерческих организаций, выявить проблемы, решение которых будет определять их дальнейшую перспективу.

\section{Теоретические и методологические основы исследования.}

Теоретическую основу исследования составили теории социального государства, теория социального партнерства и роли НКО в межсекторном взаимодействии в процессе преобразования социального государства в социально сервисное. Признанными исследователями роли НКО в сфере производства социальных благ являются Л. Саламон, Х. Анхейер, А. Этциони [28; 29]. В работах отечественных авторов А. Тарасенко, Т.Ю. Сидориной содержится подробный обзор теоретических подходов к объяснению происхождения и 
фракторов динамики НКО как производителей социальных благ [23; 25]. В исследованиях В.Б. Беневоленского, И.И. Краснопольской, И.В. Мерсияновой, Е.О. Шмулевич подробно анализируется инновационный характер деятельности социально ориентированных некоммерческих организаций как производителей социальных услуг, развивается положение об НКО как ядре гражданского общества, раскрываются институциональные преимущества и присущие им ограничения как участников рынка социальных услуг $[1 ; 3 ; 4$; 5].

В проведенном исследовании, результаты которого представлены в статье, применялись количественные и качественные методы получения социологической информации. Среди них - статистические данные, размещенные в открытых источниках, о развитии СОНКО в регионах Дальневосточного федерального округа, в частности, показатели, характеризующие негосударственных производителей услуг, размещенные в реестрах поставщиков социальных услуг Республики Саха (Якутия) и Хабаровского края. Проведен анализ нормативно-правовой базы, в соответствии с которой регулируется развитие некоммерческих организаций в этих регионах и вторичный анализ эмпирических данных, полученных в ходе социологических исследований, представленных в литературных источниках. Один из основных методов - полуструктурированные интервью с представителями НКО, социальными предпринимателями, руководителями государственных социальных учреждений. Интервью проведены с представителями 9 организаций, расположенных в Хабаровске и Якутске, информантами были 6 руководителей НКО, 1 социальный предприниматель, 2 эксперта, представляющие государственные социальные учреждения. Среди участников интервью было семь женщин и двое мужчин.

Вопросы, обсуждаемые в ходе интервью, затрагивали наиболее характерные причины создания региональных СОНКО, основные направления деятельности, реализуемые проекты, типичные проблемы развития некоммерческих организаций. Отдельный блок вопросов был посвящен взаимодействию некоммерческих организаций с государственными учреждениями, источникам фоннансирования СОНКО, отношению государственных управленческих структур и учреждений к деятельности СО НКО, возможностям, которыми они располагают для расширения спектра услуг населению и повышения их качества.

\section{Результаты исследования}

Хабаровский край и Республика Саха (Якутия) занимают ведущие позиции в развитии негосударственных организаций социального обслуживания в Дальневосточном федеральном округе. Об этом свидетельствует высокая доля некоммерческих организащий, индивидуальных предпринимателей и коммерческих предприятий, зарегистрированных в Реестре поставщиков социальных услуг, что благоприятно влияет на формирование конкурентной среды на рынке социальных услуг. К этим субъектам округа приближается по ряду позиций и рейтинговому месту Сахалинская область (табл.1). Но в то же время, как свидетельствуют данные таблицы 1, Дальневосточный округ отличается неравномерным развитием негосударственного сектора социальных услуг, а образующие его субъекты достаточно дифференцированы по показателям вовлечения в сферу услуг некоммерческого сектора. В Хабаровском крае доля негосударственных исполнителей социальных услуг в начале текущего года составляла 34,7 \%., в Республике Саха (Якутия) - 35,8 \%., в то время как, например, в Амурской области - всего $12,07 \%$ [12; 16; 19].

В каждом субъекте, составившем предмет нашего анализа, сформирована нормативно-правовая база, на основании которой регулируется развитие социально-ориентированных некоммерческих организаций на региональном уровне, что относится к важным условиям динамичного развития сферы социальных услуг (табл. 2).

В таблице 2 представлен далеко не весь перечень региональных нормативно-правовых актов, регулирующих отношения в сфере социального обслуживания, для целей проведенного анализа нам важно подчеркнуть, что принятые нормативные акты создают базу для развития управленческих, 
Таблица 1. Показатели реестров поставщиков социальных услуг Дальневосточного федерального округа

\begin{tabular}{|c|c|c|c|c|c|c|c|c|c|}
\hline № & Субъекты РФ в ДФО & 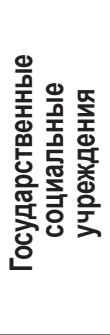 & НКО & 000 & ИП & OAO & Bcero & 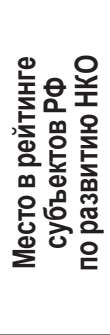 & 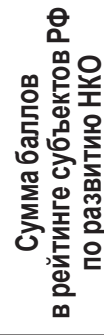 \\
\hline 1. & Хабаровский край & 45 & 21 & 1 & 2 & - & 69 & 3 & 36,58 \\
\hline 2. & Республика Саха (Якутия) & 83 & 10 & 7 & 11 & - & 111 & 7 & 32,10 \\
\hline 3. & Сахалинская область & 28 & 12 & - & 1 & 1 & 42 & 9 & 31,39 \\
\hline 4. & Еврейская автономная область & 7 & 5 & - & - & - & 12 & 23 & 27,26 \\
\hline 5. & Магаданская область & 15 & 2 & - & 2 & - & 19 & 31 & 23,20 \\
\hline 6. & Республика Бурятия & 36 & 7 & 4 & 4 & 1 & 52 & 36 & 22,40 \\
\hline 7. & Камчатский край & 21 & 5 & 1 & - & - & 27 & 54 & 19,01 \\
\hline 8. & Приморский край & 28 & 8 & - & 2 & - & 38 & 58 & 18,33 \\
\hline 9. & Амурская область & 51 & 5 & 1 & - & 1 & 58 & 60 & 17,92 \\
\hline 10. & Забайкальский край & 47 & 15 & - & 1 & - & 63 & 73 & 14,33 \\
\hline 11. & Чукотский автономный округ & 26 & 12 & 8 & 2 & - & 48 & 85 & 7,31 \\
\hline
\end{tabular}

Источник: составлено на основе $[9 ; 10 ; 11 ; 12 ; 13 ; 14 ; 15 ; 16 ; 17 ; 18 ; 19 ; 20 ; 21]$.

Таблица 2. Региональные нормативно-правовые акты, регулирующие развитие системы социального обслуживания граждан

\section{Хабаровский край}

- Закон Хабаровского края от 10.12.2014 № 21 "О реализации отдельных полномочий Хабаровского края в сфере социального обслуживания граждан"

- Распоряжение Правительства Хабаровского края от 08 февраля 2013 г. № 52-рп "Об утверждении планов мероприятий ("дорожных карт") повышения эффективности и качества услуг учреждений социальной сфреры Хабаровского края"

- Приказ министерства социальной защиты населения Хабаровского края от 27 ноября 2009 г. № 183-П "Об утверждении государственного стандарта социального обслуживания населения Хабаровского края.

- Компенсация поставщикам социальных услуг (Постановление Правительства Хабаровского края от 29 декабря 2015 г. №480-пр)

- Постановление Правительства Хабаровского края от 31.10.2014 № 416-пр "Об утверждении порядка предоставления социальных услуг в полустационарной форме получателям социальных услуг поставщиками социальных услуг в Хабаровском крае".

- Постановление Правительства Хабаровского края от 31.10.2014 N 412-пр "Об утверждении Порядка предоставления социальных услуг в стационарной форме получателям социальных услуг поставщиками социальных услуг в Хабаровском крае".

- Постановление Правительства Хабаровского края от 31.10.2014 № 417-пр "Об утверждении порядка предоставления социальных услуг на дому получателям социальных услуг поставщиками социальных услуг в Хабаровском крае"

\section{Республика Саха (Якутия)}

Закон Республики Саха (Якутия) "О социальном обслуживании граждан в Республике Саха (Якутия)" от 22.01.2015 1404-3 № 363-V. 
- Закон Республики Саха (Якутия) "Об утверждении перечня социальных услуг, предоставляемых поставщиками социальных услуг в Республике Саха (Якутия)" от 22.01.2015 1406-3 № 367-V.

- Закон Республики Саха (Якутия) "О государственной поддержке социально ориентированных некоммерческих организаций в Республике Саха (Якутия)" от 27.11.2014 1386-3 № 327-V.

- Приказ Министерства труда и социального развития Республики Саха (Якутия) "Об утверждении Порядка предоставления социальных услуг поставщиками социальных услуг" от 17.10.2014 № 775-ОД.

- Приказ Министерства труда и социального развития Республики Саха (Якутия) "Об утверждении

- Порядка формирования и ведения Реестра поставщиков социальных услуг Республики Саха (Якутия), Положения о Комиссии по рассмотрению обращений юридических лиц и индивидуальных предпринимателей, осуществляющих деятельность в сфере социального обслуживания населения, в целях их включения в Реестр поставщиков социальных услуг Республики Саха (Якутия) и Порядка формирования и ведения Регистра получателей социальных услуг Республики Саха (Якутия)" от 25.04.2016 № 1 н.

- Указ Главы Республики Саха (Якутия) "О совершенствовании механизмов государственной поддержки социально ориентированных некоммерческих организаций в Республике Саха (Якутия)" от 01.02.2018 № 2391.

Составлено на основе: $[6 ; 7 ; 8 ; 9 ; 24]$.

организационных, экономических и других условий вхождения новых участников в сферу социального обслуживания. В документах определяются основные формы поддержки СО НКО, благотворителей и добровольцев, социальных предпринимателей, осуществляющих деятельность в сфрере сощиального обслуживания, механизмы отбора и координации поставщиков социальных услуг, способы взаимодействия органов государственной власти с новыми исполнителями услуг, порядок предоставления услуг получателям. В них содержатся нормы, предписывающие организациям создание условий для профрессионального обучения и профессионального образования работников НКО и социальных предприятий, поставляющих услуги. Реализация нормативных актов нацелена в конечном счете на развитие в регионах рынка социальных услуг, фрункционирование которого способно влиять на расширение спектра и качества услуг.

К фракторам развития некоммерческого сектора относится поддержка государственными органами управления деятельности социально ориентированных НКО, которая осуществляется в форме финансовой, имущественной, информационной, консультационной поддержки, содействия в профессиональной подготовке и повышении квалификации работников и добровольцев, привлекаемых СОНКО к реализации своих мероприятий. В соответствии с законодательством региональные органы управления могут предоставлять льготы СОНКО по уплате налогов и сборов, осуществлять закупку у $\mathrm{COH}$ КО товаров, работ, услуг для обеспечения государственных и муниципальных нужд.

Среди механизмов, посредством которых происходит развитие НКО, особое место занимают ресурсные центры. Они создаются в форме НКО, выполняя фрункции консультационной, методической, информационной, имущественной, финансовой, образовательной поддержки некоммерческих организаций, содействуя их профессионализации. На территории Хабаровского края действуют такие ресурсные центры развития НКО, как Объединенный ресурсный центр поддержки СО НКО Хабаровского края, Молодежный ресурсный центр, Ресурсный центр НКО Ассамблеи народов Хабаровского края, Дальневосточный центр инноваций социальной сфреры, Центр информационной поддержки "Гражданские медиа", Дальневосточный ресурсный центр развития гражданского общества. В Республике Саха (Якутия) также функционирует несколько ресурсных центров поддержки СОНКО, предоставляющих услуги в сфрере сощиального обслуживания, в числе которых "Целевой фонд будущих поколений Республики Саха (Якутия)", "Ассоциация консультантов, финансистов и аудиторов", Ресурсный центр поддержки социально ориентированных некоммерческих организаций и активных граждан "СПАС" и другие. При региональных органах управления созданы и действуют общественные институты поддержки социально ориентированных некоммерческих организаций. В Хабаровском крае это Совет по поддержке СОНКО в составе 29 членов из числа представителей министерств, администраций муниципальных образований, руководителей НКО, в Республике Саха (Якутия) сформирован 
Координационный (совещательный) Совет по организации доступа СО НКО к оказанию социальных услуг.

В Хабаровском крае в период с 2013 по 2019 годы из регионального бюджета выделялись средства для поддержки 325 проектов СОНКО. Некоммерческими организациями на реализацию социально значимой деятельности было привлечено внебюджетных средств в объеме 123 млн. рублей. В течение 2019 года из бюджета Хабаровского края 25 СОНКО предоставлено субсидий на сумму 12,01 млн. руб. При этом размер средств, привлеченных собственными усилиями СОНКО на реализацию проектов, составил 7,45 млн. рублей. Кроме того, ресурсным центрам, оказывающим информащионную, консультационную и методическую поддержку деятельности этих организаций, предоставлено субсидий в размере 2 млн. рублей. Возмещение расходов по уставной деятельности и участию в мероприятиях в 2019 году получили 4 COНКО на сумму 248,75 тыс. рублей, еще 8 организаций получили возмещение расходов за реализацию мероприятий федерального и регионального уровней на сумму 245,92 тыс. рублей. Некоммерческие организации Хабаровского края ежегодно принимают активное участие в конкурсе Президентских грантов. В 2019 году победителями конкурса стали 36 СОНКО, общий размер привлеченных в край средств на реализацию проектов составил 53,3 млн. рублей [7]. В Республике Саха (Якутия) из государственного бюджета на выплату компенсации за оказанные социальные услуги в рамках реализации республиканских программ "Социальная поддержка граждан в Республике Саха (Якутия) на 2018-2022 годы" по мероприятию "Развитие рынка сощиальных услуг" в 2019 г. некоммерческим поставщикам было выделено 49,5 млн. рублей. С 2017 по 2018 годы в Фонд президентских грантов РФ от Республики Саха была подана 331 заявка СО НКО. Из них поддержку получили 56 проектов на сумму 61 млн. рублей. В 2019 году Якутия планировала подать не менее 400 заявок на конкурсный отбор Фонда президентских грантов РФ, в первом квартале года от северной республики было подано 95 заявок. Правительством республики планомерно реализуются задачи по содействию повышению качества проектов, квалификации специалистов муниципальных образований по работе с институтами гражданского общества и представителей социально ориентированных некоммерческих организаций [27]. В Республике внедряются цифровые технологии в сфере социальных услуг, разработано мобильное приложение "НКО Якутии", предоставляющее пользователям возможность оперативно получать информацию о некоммерческих организациях Якутии, мероприятиях, конкурсах для НКО регионального и федерального уровней. С помощью приложения можно пройти регистрацию в ЕГРЮЛ, подать документы на реорганизацию, ликвидацию, внести изменения в сведения ЕРГЮЛ, в устав НКО, задать вопросы, познакомиться с лучшими практиками деятельности НКО.

Таким образом, в регионах созданы условия развития и инструменты фоинансирования деятельности СОНКО, основными источниками которого являются президентские, региональные гранты и субсидии из региональных бюджетов, привлеченные средства в форме пожертвований, труда волонтеров, деятельности, приносящей доход для реализации уставных целей организаций. В то же время руководители организаций находятся в постоянном поиске новых направлений деятельности, обеспечивающих фринансовую устойчивость НКО, сокращая излишнюю зависимость от грантовых средств, при этом они демонстрируют стремление к освоению инновационных технологий и сохранению присущей им институциональной специфики. Об этом свидетельствуют данные, полученные нами в ходе интервью с представителями СО НКО: "Основной источник пока все-таки остается грантовая поддержка, но за последние годы мь поставили себе иель диверсифбиировать источники фбинансирования и уйти от основного фбинансового источника в виде грантов и начали развивать частные пожертвования. Сейчас у нас, скажем так, третье место в нашел бюджете составляют частные пожертвования. Основной источник все-таки гранты, гранты практически всех любых уровней, и президентские, и беедеральные других фбондов, и краевые, и мунииипальные. Ну и, кроле того, как поставщики социальных услуг мы получаел субсидию, колпенсаиию за оказаннье услуги. ... Мы сейчас думаел над созданиел иелевого капитала и у нас есть свой социальный бизнес, который 
уже начал приносить прибьль и стал ... однил из источников ббинансирования организации, планируел расширять социальньцй бизнес, вот, также мы планируел внедрять инборлмационные технологии в свою работу, поняли, что за этил будущее" (Руководитель обшественной организаиии, Хабаровск). В приведенном высказывании обозначена позиция, свидетельствующая о социальной ответственности некоммерческих организаций, понимании роли некоммерческого сектора в социальном партнерстве, его инновационного характера и относительной независимости как выразителя прежде всего интересов гражданского общества, в данном случае тех целевых социальных групп, которые нуждаются в их поддержке.

В регионах разработаны стандарты предоставления социальных услуг населению, значительная часть из которых уже предоставляется негосударственными организациями. Некоммерческие организации занимаются реабилитацией бездомных, наркозависимых, подбором персонала и трудоустройством для ухода за людьми, нуждающимися в социальном обслуживании, патронажем престарелых, инвалидов, неблагополучных семей, коррекционным обучением детей. Услуги оказывают в стационарной, полустационарной форме и на дому. Региональными органами управления планируется комплексное предоставление реабилитационных услуг для людей с инвалидности ("пакет услуг") на дому, которые будут предоставлять и СО НКО. Социальные услуги, поставляемые некоммерческими организациями, предназначены преимущественно тем социальных группам, чьи проблемы, являясь не вполне "стандартными", вызывают определенные трудности для решения в государственных учреждениях сощиального обслуживания. Один из участников интервью следующим образом сформулировал причины создания НКО, которой руководит в настоящее время "У леня стаж употребления наркотиков большой и долгий, прошел реабилитаиию, приехал в Хабаровск, обратно домой вернулся, послотрел, что подобных организаций нет. Интересно, решил попробовать и организовал организацию.... Конечно, заработок денег важен, но это не основная деятельность нашей организаиии. Основная наша иель - это полощь людял" (Руководитель АНО, Хабаровск). Как следует из интервью, типичным мотивом создания НКО выступают личные проблемы людей, инициирующих создание НКО, или членов их семей. Столкнувшись с невозможностью получить услуги в государственных учреждениях социального обслуживания, они становятся организаторами деятельности НКО. Нашим информантом сорормулирована и социальная миссия некоммерческой организации, которой он руководит, - помощь людям в решении проблем, вызывающих трудности в их жизни, и которые они не могут самостоятельно преодолеть.

Анализ практического участия негосударственных организаций в социальном обслуживании населения показывает, что не все зарегистрированные региональные НКО, позиционируя себя как социально ориентированные, входят в реестры поставщиков социальных услуг. Так, в Хабаровском крае в конце 2019 года было зарегистрировано $2283 \mathrm{HКО,} \mathrm{около} \mathrm{70 \%} \mathrm{из} \mathrm{них} \mathrm{признаны}$ социально ориентированными некоммерческими организациями. Но лишь небольшое число организаций, как следует из приведенных выше данных, в настоящее время имеют статус поставщиков социальных услуг, это может свидетельствовать о наличии барьеров, препятствующих включению СОНКО в реестр поставщиков услуг. Во-первых, организации могут не соответствовать критериям отбора поставщиков, которые устанавливаются региональными органами управления. Во-вторых, организации сами не стремятся войти в реестр, поскольку их может не устраивать порядок предоставления услуг, формирования отчетности, низкие тарифы на оказанные населению услуги, при которых возмещение затрат за предоставленные населению услуги не покрывает их расходов, поэтому некоммерческим организациям становится невыгодно входить в число поставщиков услуг, включенных в региональный реестр. В-третьих, институциональная особенность НКО в том и заключается, что им в своей деятельности, направленной на удовлетворение запросов своих целевых социальных групп, в интересах которых они создаются, необходимо опираться на труд добровольцев, привлекать средства благотворителей, заниматься реализацией социальных проектов и т.п. Однако на практике не каждая некоммерческая организация готова и способна к выполнению этих 
функций, например, из-за неподготовленности своих сотрудников, руководителей или других причин. Наконец, во внимание необходимо принимать отношение населения к новым исполнителям социальных услуг, доверие или недоверие им.

На выделенные выше фракторы, затрудняющие развитие СОНКО, обращали внимание участники интервью: "...За услуги, допустил, соииальное обслуживание, мы получаел субсидии государственные от Министерства труда, но тал небольшие сулмь, конечно" (Председатель СО НКО, Якутск). Среди сдерживающих причин развития НКО как поставщиков услуг информанты называли сохраняющееся у населения доверие преимущественно к государственным учреждениям и недоверие к негосударственным организациям: "...Если система НКО будет дальше развиваться, то государственнолу сектору будет легче работать, напльва граждан не будет, но сейчас люди при возникновении проблель сразу бегут в государственные учреждения, потолу что еще не доверяют НКО, ИП и ООО" (Индивидуальньий предприниматель, оказываюший соииальные услуги, Якутск).

Специалист государственного учреждения, называя фракторы, затрудняющие развитие в регионе негосударственного сектора социальных услуг, сформулировала несколько из них: "Существует круг проблел, связанных с расширениел участия неколмерческих организаций в оказании социальных услуг населению: правовые и организационные коллизии, возникаюшие в связи с появлениел новых видов НКО. Нечеткие и необязательнье критерии оценки результатов деятельности соииально ориентированньх НКО; недостаток ббинансирования и чрезлерная зависилость от личньх средств организаций. Иноборлаиионная закрьтость" (Специалист государственного социально-реабилитационного иентра для несовершеннолетних, Якутск).

Имеющиеся в литературных источниках результаты эмпирических исследований, проведенных в Дальневосточных регионах, подтверждают названные нашими информантами причины, сдерживающие развитие НКО. Так, авторы одного из социологических исследований, которое проводилось в РС(Я), отмечают, что большинство респондентов среди фракторов, создающих проблемы для развития СОНКО, называют низкие тарифы на услуги населению, сложность процедур, связанных с предоставлением отчетности при возмещение затрат, трудности продвижения инновационных услуг. [22, с. 59].

Вместе с тем участники интервью высоко оценили взаимодействие региональных органов управления с некоммерческими организациями. "C государственныли органали льь очень хорошо контактируел и с луниципальньлми образованияли. ... У нас сальй главныцй куратор и координатор - это Министерство труда и социального развития Республики Саха (Якутия), ...по инклюзивнолу образованию и по ранней полоши работаел с Министерствол образования Республики Саха (Якутия), по адаптивной ббзкультуре с Министерствол спорта Республики Саха (Якутия). (Председатель совеmа благотворительного бонда, Якутск). В Республике Саха (Якутия), как следует из интервью, отчетливо прослеживается межведомственный подход к актуальным социальным проблемам, в решение которых вовлечены СОНКО. Социальное партнерство государства с некоммерческими организациями оказывает положительное влияние на формирование новых организационных моделей предоставления социальных услуг в регионе: "...У нас такой соииальный холдинг, где государственное ведолство создало платбборлу, полешение содержат, сотрудники есть, которье получают зарплату из бюджета, а рядол еше несколько НКО, которые берут на себя проблелнье моленты и пологают их решить, и тел сальлм наполняют обшую колплексную помошь, сеглент большой мы создаел. И ль показываел власти, что реально вот так вот взаилодействовать игрокал разньх борл, бюджетнье и НКО" (Директор $A H O$, Хабаровск). В данном случае государственные организации и СОНКО, сотрудничая, демонстрируют инновационный подход к организации комплексного решения проблем детей, страдающих расстройством аутистического спектра, и их семей, нуждающихся в совокупности услуг, которые не в состоянии обеспечить только государственные социальные учреждения. 


\section{Заключение}

Проведенный анализ в ходе изучения фракторов, определивших лидерские позиции в развитии СОНКО Хабаровского края и РС(Я), дает основание полагать, что одним из решающих фракторов выступают инициативы самих некоммерческих организаций, которые находят поддержку у региональных органов управления. Появление НКО часто связано с личной мотивацией их организаторов, но их деятельность получает общественную значимость в том случае, если совпадает с объективными потребностями в решении социальных проблем населения территории, на которой действуют некоммерческие организации, что и обеспечивает им поддержку со стороны региональных управленческих структур.

СОНКО более конкурентоспособны по сравнению с государственными социальными учреждениями при решении "нестандартных проблем" тех целевых групп, для помощи которым они создаются и в интересах которых действуют. Именно такие группы становятся получателями услуг некоммерческих организаций. $\mathrm{K}$ этому следует добавить их гибкость в реагировании на возникающие проблемы у населения, способность обеспечить индивидуальный подход к получателям услуг, возможность специализироваться на услугах, которые востребованы среди людей, нуждающихся в социальном обслуживании, достигая тем самым необходимого качества.

Особенность региональных СОНКО Дальневосточного федерального округа, деятельность которых составила предмет исследования, состоит в том, что на данном этапе развития они проявили отчетливо выраженную тенденцию к сотрудничеству между собой и с существующими государственными социальными учреждениями, что составляет существенный ресурс их дальнейшего продвижения как поставщиков социальных услуг.

\section{Литература}

1. Беневоленский В.Б., Шмулевич Е.О. Государственная поддержка социально ориентированных НКО в свете зарубежного опыта // Вопросы государственного и муниципального управления. 2013. № 3. С. 66-73.

2. Заболотная Г.М., Ларионов А.В. Региональные практики институционализации негосударственных поставщиков социальных услуг // Вопросы государственного и муниципального управления. 2017. № 3. С. 72-91.

3. Краснопольская И.И., Мерсиянова И.В. Трансформация управления социальной сферой: запрос на социальные инновации // Вопросы государственного и муниципального управления. 2015. № 2. С. 29-47.

4. Мерсиянова И.В., Беневоленский В.Б. Преимущества НКО как поставщиков социальных услуг: апробация в российских условиях // Вопросы государственного и муниципального управления. 2016. № 4. С. 7-26.

5. Мерсиянова И.В., Беневоленский В.Б. НКО как поставщики сощиальных услуг: верификация слабых сторон // Вопросы государственного и муниципального управления. 2017. № 2. С. 83-104.

6. Информационно-консультационная поддержка гражданских инициатив. Гражданское общество Хабаровского края. [Электронный ресурс]. URL: https://nko27. ru/ (дата обращения: 05.08.2020).

7. Некоммерческие организации (НКО). Гражданское общество Хабаровска. [Электронный ресурс]. URL: https://nko.khabarovskadm.ru/obshchestvennyeorganizatsii/ baz\%D0\%B5-nko/ (дата обращения: 05.08.2020).

8. Официальный информационный портал республики Саха(Якутия). Нормативные правовые документы. [Электронный pecypc]. URL: https://sakha.gov.ru/npa/ front (дата обращения: 06.08.2020).

9. Развитие рынка услуг в сфере социального обслуживания населения. Официальный портал учреждений социальной поддержки и социального обслуживания населения Хабаровского края. [Электронный ресурс]. URL: https://mszn27.ru/service market (дата обращения: 05.08.2020).

10. Распоряжение Правительства РФ N 1284-р от 19.06.2017. Об утверждении перечня показателей, используемых для расчета рейтинга субъектов Российской Федеращии.

11. Реестр поставщиков социальных услуг (таблица). Интерактивный портал Министерства труда и социальной политики Приморского края. [Электронный ресурс]. URL: https://soctrud.primorsky.ru/content/1_pеeстр_поставщиков_социальных_услуг таблица_ (дата обращения: 07.08.2020). 
12. Реестр поставщиков социальных услуг Амурской области. Портал Правительства Амурской области. [Электронный pecypc]. URL: https://szn.amurobl. ru/pages/ deyatelnost-ministerstva/sotsialnoe-obsluzhivanie/reestr-postavshchikovsotsialnykhuslug-amurskoy-oblasti/ (дата обращения: 05.08.2020).

13. Реестр поставщиков социальных услуг в Забайкальском крае. Министерство труда и социальной защиты населения Забайкальского края. [Электронный pecypc]. URL: https://minsoc.75.ru/deyatel-nost/social-noe-obsluzhivanie-442fz/reestrpostavschikov-social-nyh-uslug-zabaykal-skogo-kraya (дата обращения: 07.08.2020).

14. Реестр поставщиков социальных услуг Еврейской автономной области. Социальная защита Еврейской автономной области. [Электронный ресурс]. URL: http:// social.eao.ru/?page_id=1037 (дата обращения: 06.08.2020).

15. Реестр поставщиков сощиальных услуг Магаданской области. ООО СоцИнформTех. [Электронный ресурc]. URL: http://msp.49gov.ru/rpost/reestr.html?PageSize= 10\&Sort=0\&PageNumber=1 (дата обращения: 07.08.2020).

16. Реестр поставщиков социальных услуг РС (Я). Министерство труда и социального развития Республики Саха (Якутия). [Электронный ресурс]. URL: https://mintrud. sakha.gov.ru/doki1/reestr-postavschikov-sotsialnyh-uslug (дата обращения 05.08.2020)

17. Реестр поставщиков социальных услуг Сахалинской области. Официальный сайт Министерства социальной защиты Сахалинской области. [Электронный ресурс]. URL: https://msz.admsakhalin.ru/reestr/reestr.html?PageSize=10\&Sort=0\&PageNumb er=1 (дата обращения: 05.08.2020).

18. Реестр поставщиков социальных услуг. Министерство социального развития и труда Камчатского края. [Электронный ресурс]. URL: http://old.kamgov.ru/?cont=oiv_di n\&mcont=5657\&menu=4\&menu2=0\&id=174 (дата обращения: 06.08.2020).

19. Реестр поставщиков социальных услуг. Министерство сощиальной защиты Хабаровского края. [Электронный ресурс]. URL: https://socuslugi.mszn27.ru/sonhub/ orglist.html (дата обращения: 05.08.2020).

20. Реестр поставщиков социальных услуг. Республиканское государственное учреждение "Центр сощиальной поддержки населения" Министерства социальной защиты населения Республики Бурятия. [Электронный ресурc]. URL: http://www.cspn-rb. ru/reestr_postavshchikov_sotsialnykh_uslug/ (дата обращения: 06.08.2020).

21. Реестр социально ориентированных организаций. Министерство здравоохранения Хабаровского края. [Электронный ресурc]. URL: https://zdrav.khv.gov.ru/ node/4046 (дата обращения: 05.08.2020).

22. Седалищева Э.Н., Макарова А.П. Развитие негосударственных форм социального обслуживания в Республике Саха (Якутия) // Казанский социально-гуманитарный вестник. 2018. № 3 (32). С.59-62.

23. Сидорина Т.Ю. Партнерство государства и институтов самоорганизации граждан в реализации социальной политики (теоретический аспект) // Terra Economicus. 2010. № 8 (1). C. 117-129.

24. Содействие развитию институтов и инищиатив гражданского общества в Хабаровском крае. [Электронный ресурс]. Режим доступа: https://www.khabkrai.ru/ khabarovsk-krai/Proekty/Gosudarstvennye-celevye-programmy/162 (дата обращения: 04.08.2020).

25. Тарасенко А. Концепты третьего сектора и гражданского общества в контексте теорий демократии, управления и экономического развития. 2014. [Электронный pecypc]. URL: https://eusp.org/sites/default/files/archive/centres/M-center/M_36_14.pdf (дата обращения: 29 марта 2020).

26. Тополева-Солдунова Е.А. (ред.) Участие НКО в оказании услуг в социальной сфере (Специальный доклад Общественной палаты Российской Федерации). Москва: "Современные информационные системы", 2019. 96 с.

27. Якутия подаст не менее 400 заявок в Фонд президентских грантов // Информационно-аналитический портал SakhaNews. [Электронный ресурc]. URL: https:// www.1sn.ru/226354.html (дата обращения: 30.07.2020

28. Salamon, L. M., Anheier, H. K. Social origins of civil society: Explaining the nonprofit sector cross-nationally // Voluntas: International journal of voluntary and nonprofit organizations. 1998. № 3(9). Pp. 213-248.

29. Etzioni A. The Third Sector and Domestic Missions // Public Administration Review. 1973. № 33 (4). Pp. $314-323$.

\section{Транслитерация по ГОСТ 7.79-2000 Система Б}

1. Benevolenskij V.B., SHmulevich E.O. Gosudarstvennaya podderzhka sotsial'no orientirovannykh NKO v svete zarubezhnogo opyta // Voprosy gosudarstvennogo i munitsipal'nogo upravleniya. 2013. № 3. S. 66-73. 
2. Zabolotnaya G.M., Larionov A.V. Regional'nye praktiki institutsionalizatsii negosudarstvennykh postavshhikov sotsial'nykh uslug // Voprosy gosudarstvennogo i munitsipal'nogo upravleniya. 2017. № 3. S. 72-91.

3. Krasnopol'skaya I.I., Mersiyanova I.V. Transformatsiya upravleniya sotsial'noj sferoj: zapros na sotsial'nye innovatsii // Voprosy gosudarstvennogo i munitsipal'nogo upravleniya. 2015. № 2. S. 29-47.

4. Mersiyanova I.V., Benevolenskij V.B. Preimushhestva NKO kak postavshhikov sotsial'nykh uslug: aprobatsiya v rossijskikh usloviyakh // Voprosy gosudarstvennogo i munitsipal'nogo upravleniya. 2016. № 4. S. 7-26.

5. Mersiyanova I.V., Benevolenskij V.B. NKO kak postavshhiki sotsial'nykh uslug: verifikatsiya slabykh storon // Voprosy gosudarstvennogo i munitsipal'nogo upravleniya. 2017. № 2. S. 83-104.

6. Informatsionno-konsul'tatsionnaya podderzhka grazhdanskikh initsiativ. Grazhdanskoe obshhestvo KHabarovskogo kraya. [EHlektronnyj resurs]. URL: https://nko27. ru/ (data obrashheniya: 05.08.2020).

7. Nekommercheskie organizatsii (NKO). Grazhdanskoe obshhestvo KHabarovska. [EHlektronnyj resurs]. URL: https://nko.khabarovskadm.ru/obshchestvennyeorganizatsii/ baz\%D0\%B5-nko/ (data obrashheniya: 05.08.2020).

8. Ofitsial'nyj informatsionnyj portal respubliki Sakha(YAkutiya). Normativnye pravovye dokumenty. [EHlektronnyj resurs]. URL: https://sakha.gov.ru/npa/ front (data obrashheniya: 06.08.2020).

9. Razvitie rynka uslug v sfere sotsial'nogo obsluzhivaniya naseleniya. Ofitsial'nyj portal uchrezhdenij sotsial'noj podderzhki i sotsial'nogo obsluzhivaniya naseleniya KHabarovskogo kraya. [EHlektronnyj resurs]. URL: https://mszn27.ru/service_ market (data obrashheniya: 05.08.2020).

10. Rasporyazhenie Pravitel'stva RF N 1284-r ot 19.06.2017. Ob utverzhdenii perechnya pokazatelej, ispol'zuemykh dlya rascheta rejtinga sub"ektov Rossijskoj Federatsii.

11. Reestr postavshhikov sotsial'nykh uslug (tablitsa). Interaktivnyj portal Ministerstva truda i sotsial'noj politiki Primorskogo kraya. [EHlektronnyj resurs]. URL: https:// soctrud.primorsky.ru/content/1_reestr_postavshhikov_sotsial'nykh_uslug tablitsa_(data obrashheniya: 07.08.2020)

12. Reestr postavshhikov sotsial'nykh uslug Amurskoj oblasti. Portal Pravitel'stva Amurskoj oblasti. [EHlektronnyj resurs]. URL: https://szn.amurobl.ru/pages/ deyatelnost-ministerstva/sotsialnoe-obsluzhivanie/reestr-postavshchikov-sotsialnykhuslug-amurskoy-oblasti/ (data obrashheniya: 05.08.2020).

13. Reestr postavshhikov sotsial'nykh uslug v Zabajkal'skom krae. Ministerstvo truda i sotsial'noj zashhity naseleniya Zabajkal'skogo kraya. [EHlektronnyj resurs]. URL: https://minsoc.75.ru/deyatel-nost/social-noe-obsluzhivanie-442-fz/reestrpostavschikov-social-nyh-uslug-zabaykal-skogo-kraya (data obrashheniya: 07.08.2020).

14. Reestr postavshhikov sotsial'nykh uslug Evrejskoj avtonomnoj oblasti. Sotsial'naya zashhita Evrejskoj avtonomnoj oblasti. [EHlektronnyj resurs]. URL: http:// social. eao.ru/?page_id=1037 (data obrashheniya: 06.08.2020).

15. Reestr postavshhikov sotsial'nykh uslug Magadanskoj oblasti. OOO SotsInformTekh. [EHlektronnyj resurs]. URL: http://msp.49gov.ru/rpost/reestr.html?PageSize= 10\&Sort=0\&PageNumber $=1$ (data obrashheniya: 07.08.2020).

16. Reestr postavshhikov sotsial'nykh uslug RS (YA). Ministerstvo truda i sotsial'nogo razvitiya Respubliki Sakha (YAkutiya). [EHlektronnyj resurs]. URL: https://mintrud. sakha.gov.ru/doki1/reestr-postavschikov-sotsialnyh-uslug (data obrashheniya 05.08.2020)

17. Reestr postavshhikov sotsial'nykh uslug Sakhalinskoj oblasti. Ofitsial'nyj sajt Ministerstva sotsial'noj zashhity Sakhalinskoj oblasti. [EHlektronnyj resurs]. URL: https://msz.admsakhalin.ru/reestr/reestr.html?PageSize=10\&Sort=0\&PageNumb er=1 (data obrashheniya: 05.08.2020).

18. Reestr postavshhikov sotsial'nykh uslug. Ministerstvo sotsial'nogo razvitiya i truda Kamchatskogo kraya. [EHlektronnyj resurs]. URL: http://old.kamgov.ru/?cont=oiv_di n\&mcont $=5657 \&$ menu $=4 \&$ menu2 $=0 \& i d=174$ (data obrashheniya: 06.08.2020).

19. Reestr postavshhikov sotsial'nykh uslug. Ministerstvo sotsial'noj zashhity KHabarovskogo kraya. [EHlektronnyj resurs]. URL: https://socuslugi.mszn27.ru/sonhub/ orglist.html (data obrashheniya: 05.08.2020).

20. Reestr postavshhikov sotsial'nykh uslug. Respublikanskoe gosudarstvennoe uchrezhdenie "TSentr sotsial'noj podderzhki naseleniya" Ministerstva sotsial'noj zashhity naseleniya Respubliki Buryatiya. [EHlektronnyj resurs]. URL: http://www.cspn-rb. ru/reestr_postavshchikov_sotsialnykh_uslug/ (data obrashheniya: 06.08.2020).

21. Reestr sotsial'no orientirovannykh organizatsij. Ministerstvo zdravookhraneniya KHabarovskogo kraya. [EHlektronnyj resurs]. URL: https://zdrav.khv.gov.ru/ node/4046 (data obrashheniya: 05.08.2020).

22. Sedalishheva EH.N., Makarova A.P. Razvitie negosudarstvennykh form sotsial'nogo obsluzhivaniya v Respublike Sakha (YAkutiya) // Kazanskij sotsial'no-gumanitarnyj vestnik. 2018. № 3 (32). S.59-62. 
23. Sidorina T.YU. Partnerstvo gosudarstva i institutov samoorganizatsii grazhdan v realizatsii sotsial'noj politiki (teoreticheskij aspekt) // Terra Economicus. 2010. № 8 (1). S. $117-129$.

24. Sodejstvie razvitiyu institutov i initsiativ grazhdanskogo obshhestva v KHabarovskom krae. [EHlektronnyj resurs]. Rezhim dostupa: https://www.khabkrai.ru/ khabarovsk-krai/Proekty/Gosudarstvennye-celevye-programmy/162 (data obrashheniya: 04.08.2020).

25. Tarasenko A. Kontsepty tret'ego sektora i grazhdanskogo obshhestva v kontekste teorij demokratii, upravleniya i ehkonomicheskogo razvitiya. 2014. [EHlektronnyj resurs]. URL: https://eusp.org/sites/default/files/archive/centres/M-center/M_36_14.pdf (data obrashheniya: 29 marta 2020).

26. Topoleva-Soldunova E.A. (red.) Uchastie NKO v okazanii uslug v sotsial'noj sfere (Spetsial'nyj doklad Obshhestvennoj palaty Rossijskoj Federatsii). Moskva: "Sovremennye informatsionnye sistemy", 2019. $96 \mathrm{~s}$.

27. YAkutiya podact ne menee 400 zayavok v Fond prezidentskikh grantov // Informatsionno-analiticheskij portal SakhaNews. [EHlektronnyj resurs]. URL: https:// www.1sn.ru/226354.html (data obrashheniya: 30.07.2020

28. Salamon, L. M., Anheier, H. K. Social origins of civil society: Explaining the nonprofit sector cross-nationally // Voluntas: International journal of voluntary and nonprofit organizations. 1998. № 3(9). Pp. 213-248.

29. Etzioni A. The Third Sector and Domestic Missions // Public Administration Review. 1973. № 33 (4). Pp. 314 - 323.

Старшинова А. В., Платонова Л. А. Развитие НКО как поставщиков социальных услуг в регионах Дальневосточного округа.

На основе статистической, нормативно-правовой и социологической информации проведен анализ основных условий развития НКО в Хабаровском крае и Республике Саха (Якутия), относящихся к группе регионов, лидирующих в России по показателям вовлечения некоммерческого сектора в сферу социального обслуживания населения. Результаты исследования дают основание утверждать, что наряду с правовыми, организационными, управленческими, иными фракторами, определяющими развитие социально ориентированных НКО, решающее значение приобретают собственные инициативы СОНКО, способность к инновациям, сотрудничеству с основными акторами формирующегося рынка социальных услуг, гибкому реагированию на запросы населения.

Ключевые слова: социально ориентированные НКО, социальное партнерство, социальные услуги, поставщики социальных услуг, реестр поставщиков услуг

Starshinova A. V., Platonova L. A. Development of NPOs as providers of social services in the regions of the Far Eastern District.

On the basis of statistical and sociological information, the analysis of the main conditions for the development of non-profit organizations in the Khabarovsk Territory and the Republic of Sakha (Yakutia), which belong to the group of regions leading in Russia in terms of the formation of the non-profit sector in the field of social services to the population, is carried out. The study showed that along with the legal, organizational, managerial, and other factors that determine the development of socially oriented NGOs, SONGO's own initiatives, the ability to innovate, cooperation with the main actors of the emerging market of social services, flexible response to population requests are of decisive importance.

Key words: socially oriented NGOs, social partnership, social services, social service providers, register of service providers

Для цитирования: Старшинова А. В., Платонова Л. А. Развитие НКО как поставщиков социальных услуг в регионах Дальневосточного округа // Ойкумена. Регионоведческие исследования. 2020. № 4. С. 83-94. DOI: 10.24866/1998-6785/2020-4/83-94

For citation: Starshinova A. V., Platonova L. A. Development of NPOs as providers of social services in the regions of the Far Eastern District // Ojkumena. Regional researches. 2020. № 4. P. 83-94. DOI: 10.24866/1998-6785/2020-4/83-94 